\title{
Aktualisasi Peran dan Tantangan Perguruan Tinggi Islam dalam Pencerahan dan Pencerdasan
}

\author{
A. Marjuni \\ Fakultas Tarbiyah dan Keguruan UIN Alauddin Makassar \\ h.marjunij@yahoo.com
}

\begin{abstract}
This article elaborates the actualisation and challenges of Islamic Higher Education (PTAI). This study shows that PTAIs are not only a transfer or transfer of knowledge institution, but they are also able to support the students and the community in developing its potential. In the case of the FKTK of UIN Alauddin, this study shows that the faculty's response to social change with the effort to build intelligence and broaden the horizons, build a work ethic and apply a positive-active curriculum, and perform scientific integrations. It thus becomes crucial effort in order to prepare learners to become human resources with high academic ability and social sensitivity. The study, hence, recommends that the PTAIs should orient themselves to the future by applying the pillars of true education, namely: learning to know, learning to do, learning to be, and learning to live together.
\end{abstract}

\begin{abstract}
Abstrak
Artikel ini mengeksplorasi aktualisasi dan tantangan Perguruan Tinggi Agama Islam (PTAI). Studi ini menunjukkan bahwa PTAI bukanlah merupakan pengalihan atau transfer of knowledge belaka melainkan manpu membantu para mahasiswa dan masyarakat dalam mengembangkan potensinya. Dalam kasus FKTK UIN Alauddin, studi ini menunjukkan bahwa respon fakultas ini terhadap perubahan sosial dengan usaha membangun kecerdasan dan memperluas wawasan, membangun etos kerja dan menerapkan kurikulum aktifpositif, serta melakukan integarasi keilmuan. Hal demikian menjadi penting dalam rangka menyiapkan peserta didik utnuk mejadi sumber daya manusia yang memiliki kemampuan akademik dan kepekaan social yang tinggi. Studi merekomendasikan bahwa PTAI harus berorientasi kedepan dengan menerapkan pilar pendidikan sejati yakni: learning to know, learning to do, learning to be, dan learning to live together.
\end{abstract}

Keywords: Pendidikan Tinggi, Pendidikan Tinggi Islam, Pendidikan 


\section{A. Pendahuluan}

Aktualisasi peran pendidikan tinggi Islam pada tahapan wacana secara umum dapat dipahami sebagai sebuah proyek pendewasaan sosial manusia menuju upaya ideal terbentuknya manusia seutuhnya (insan kamil) atau sebagai sebuah proses menuju tercapainya humanisme universal. ${ }^{1}$ Makna lain yang terkandung di dalamnya menyangkut pemeliharaan dan pengembangan terhadap fitrah manusia sebagai suatu potensi setiap orang sejak lahir. Penghargaan dan pengakuan atas kebebasan untuk berkembang dan berpikir progresif termasuk bebas dalam aktualisasi diri mengisi dan membentuk sejarah manusia sendiri sebagai subjek dan tak terkecuali masyarakat kepulauan, bukan justru kebebasan itu dibungkam dan dibuat tidak berdaya oleh pranata sosial yang namanya pendidikan yang oleh Freire disebutnya dengan kebudayaan bisu (the cultural of silence) yang terus menerus dilanggengkan demi kepentingan status quo. ${ }^{2}$

Realitas pendidikan di atas menjadi rentang dari sebuah proses dehumanisasi, ${ }^{3}$ sebab keberadaan peserta didik/para alumni tidak lagi sebagai manusia sejati yakni sebagai pelaku atau subyek yang memiliki potensi untuk berpikir dan memiliki kesadaran, melainkan ia telah direduksi menjadi penderita atau obyek. inilah kemudian yang oleh Paulo Freire disebut dengan "pendidikan gaya bank". 4 Praktis pada tahapan selanjutnya akan muncul kolompok masyarakat "terbelakang" dan bodoh atau lahirnya kelompok-kolompok yang merupakan akibat dari tindasan struktural yang otoriter, suatu kondisi di mana kesadaran dan sikap kritis tidak pernah didorong dan ditumbuhkan, bahkan cenderung untuk dimatikan, dengan demikian domestikasi yang dilakukan oleh struktur negara melalui penyeragaman cara berpikir yang telah diinternalisasi

\footnotetext{
${ }^{1}$ H.A.R. Tilaar, Pendidikan, Kebudayaan dan Masyarakat Madani Indonesia (Cet. III; Bandung: PT Remaja Rosdakarya, 2014), h. 17-18. Lihat pula, Muh. Khanif Dhakiri, Paulo Freire, Islam dan Pembebasan (Cet. IV; Jakarta: Pena, 2008), h. $3 .$.

${ }^{2}$ Paulo Freire. The Politic Of Education; Culture, Power, and Liberation. Diterjemahkan oleh Agung Prihantoro, dengan judul Politik Pendidikan; Kebudayaan, Kekuasaan dan Pembebasan (Cet. VI; Yogyakarta: Pustaka Pelajar, 2007), h. 11. Lihat pula, Neil Postman, The End Of Education Diterjemahkan oleh Ade Ma'ruf bersama Siti Farida, dengan judul Matinya Pendidikan (Cet. III; Yogyakarta : Jendela. 2009), h. 165-166.

${ }^{3}$ Paulo Freire, Menggugat Pendidikan; Fundamentalisme, konservatisme, liberal, (Cet. IV; Yogyakarta: Pustaka Pelajar, 2014), h. 435.

${ }^{4}$ Muslih Usah dan Aden Wijdan SZ, Pendidikan Islam dalam Perdaban Industrial (Cet. I; Yogyakarta: Adiyatya Media, 2007), h. 59.
} 
oleh pendidikan dalam waktu cukup lama, mengakibatkan kesadaran yang muncul dari para alumni bukanlah kesadaran kritis sebagai manusia yang punya pikiran dan hati nurani, melainkan kesadaran naif yang bertumpu pada pemikiran pragmatis.

Realitas pendidikan di atas yang telah berlangsung cukup lama pada gilirannya menghancurkan tatanan masyarakat demokratis yang menjadi impian semua kalangan. Pendidikan Islam telah kehilangan elan vital perjuangannya, yaitu upaya pendewasaan dan pembebasan manusia dari segala bentuk eksploitasi, diskriminasi dan penindasan khususnya yang berada pada daerah pesisir/kepulauan. Kenyataan pendidikan yang jauh dari upaya penolakan terhadap segala bentuk subordinasi tersebut adalah pelencengan dan pengkhianatan terhadap misi kemanusiaan dan transendensi pendidikan. ${ }^{5}$

\section{B. Peran Lembaga Pendidikan Tinggi Islam pada Fakultas Tarbiyah dan Keguruan UIN Alauddin Makassar}

Pengelolaan Fakultas Tarbiyah dan Keguruan UIN Alauddin Makassar tidak hanya perlu dilihat sebagai pusat ilmu pengetahuan, pusat penelitian, dan pusat pengabdian kepada masyarakat, tetapi juga suatu entitas korporat atau penghasil ilmu pengetahuan yang perlu bersaing untuk menjamin kelangsungan hidup. Persaingan, sebagaimana dialami oleh perusahaan profit, meliputi persaingan di bidang mutu, harga, dan layanan. Fakultas Tarbiyah dan Keguruan UIN Alauddin Makassar sebagai perguruan tinggi negeri sebagai suatu entitas non profit, menghadapi hal yang sama pula. Pengelolaan semuanya memerlukan pengetahuan dan ketrampilan manajemen, yaitu manajemen perguruan tinggi. ${ }^{6}$

Fakultas Tarbiyah dan Keguruan UIN Alauddin Makassar merupakan salah satu penyelenggara pendidikan Islam dengan tujuan sebagai berikut:

1. Menyiapkan peserta didik menjadi anggota masyarakat yang memiliki kemampuan akademik dan atau profesional yang dapat menerapkan, mengembangkan dan atau memperkaya khasanah ilmu pengetahuan, teknologi dan atau kesenian.

2. Mengembangkan dan menyebarluaskan ilmu pengetahuan, teknologi, dan kesenian serta mengupayakan penggunaannya untuk

\footnotetext{
${ }^{5}$ Lihat. Rusli Karim, Pendidikan Di Indonesia; Antara Cita dan Fakta, op cit., h. 31.

${ }^{6}$ Profil Fakultas Tarbiyah dan Keguruan UIN Alauddin Makassar 2006, h. 4.
} 
meningkatkan taraf kehidupan masyarakat dan memperkaya kebudayaan nasional. ${ }^{7}$

Fakultas Tarbiyah dan Keguruan UIN Alauddin Makassar sebagai pendidikan tinggi terdiri atas pendidikan akademik dan pendidikan profesional. Pendidikan akademik merupakan pendidikan yang diarahkan, terutama pada penguasaan ilmu pengetahuan, sedangkan pendidikan profesional merupakan pendidikan yang diarahkan terutama pada kesiapan penerapan keahlian tertentu. ${ }^{8}$

Fakultas Tarbiyah dan Keguruan UIN Alauddin Makassar menyelenggara-kan pendidikan tinggi, penelitian, serta pengabdian kepada masyarakat. Fakultas Tarbiyah dan Keguruan UIN Alauddin Makassar sebagai perguruan tinggi merupakan kegiatan dalam upaya menghasilkan manusia terdidik. Penelitian merupakan kegiatan telaah taat kaidah dalam upaya menemukan kebenaran dan atau menyelesaikan masalah dalam ilmu pengetahuan, dan teknologi. Pengabdian kepada masyarakat merupakan kegiatan yang memanfaatkan ilmu pengetahuan dalam upaya memberikan sumbangan demi kemajuan masyarakat. Perguruan tinggi dapat berbentuk akademik, sekolah tinggi, Institut atau universitas. Manajemen Perguruan Tinggi harus mempersiapkan berbagai aspek dalam mengatur kegiatan-kegiatan yang tercakup dalam Tri Dharma Perguruan Tinggi, yakni Pendidikan dan Pengajaran, Penelitian dan Pengabdian kepada Masyarakat. ${ }^{9}$

Fakultas Tarbiyah dan Keguruan UIN Alauddin Makassar merupakan salah satu fakultas yang konsen terhadap pengembangan sumber daya manusia yang berbasis keagamaan dan kemasyarakatan. Dalam menyelenggarakan pendidikan Islam harus menyuburkan dan mengembangkan eksistensi peserta didik seoptimal mungkin yang dilaksanakan melalui proses pendidikan yang bermartabat, kreatif, inovatif, experimentative, menumbuhkan dan mengembang-kan bakat, minat, dan kemampuan peserta didik.

Esensi Pendidikan Islam pada Fakultas Tarbiyah dan Keguruan UIN Alauddin Makassar mengisyaratkan bahwa pendidikan harus

\footnotetext{
${ }^{7}$ Mappanganro, Dosen Fakultas Tarbiyah dan Keguruan UIN Alauddin Makassar, Wawancara di Makassar pada tanggal 21 Agustus 2017.

${ }^{8}$ Amri, Dekan Fakultas Tarbiyah dan Keguruan wawancara di Makassar pada tanggal 19 September 2016.

${ }^{9}$ Amri, Dekan Fakultas Tarbiyah dan Keguruan wawancara di Makassar pada tanggal 19 September 2016.
} 
berfungsi dan relevan dengan kebutuhan, baik kebutuhan individu, keluarga, sosial, maupun kebutuhan berbagai sektor dan sub-sub sektornya baik lokal, nasional maupun Internasional. Terkait dengan tuntutan globalisasi, program studi pendidikan harus menyiapkan sumberdaya manusia Indonesia yang mampu bersaing secara internasional.

Dalam sebuah organisasi kependidikan khususnya pada Fakultas Tarbiyah dan Keguruan tentu punya kekuatan dan kelemahan. Tetapi pengelolaanya tidak dapat diselesaikan dalam jangka waktu pendek. Kekuatan dan kelemahan berada dalam lingkungan struktur, budaya dan sumber daya organisasi atau perusahaan. Struktur adalah cara suatu organisasi dalam arti komunikasi, otorisasi dan aliran kerja. Budaya meliputi kebiasaan, tradisi, kepercayaan, nilai dan harapan yang dihayati oleh pengelola. Kemudian sumber daya dalam aset yang dimiliki oleh pengelola berupa kekuatan keuangan, keahlian dan kemampuan dosen dan karyawan fasilitas serta peralatan dalam pengelolalaan dalam sumber pembelajaran.

Keunggulan yang dimiliki Fakultas Tarbiyah dan Keguruan yaitu;

1. Pengalaman dalam pengelolaan pendidikan sudah cukup lama.

2. Kepangkatan dan pendidikan para dosen yang mencukupi.

3. Masih banyak peminat Program Studi yang ada pada Fakultas Tarbiyah dan Keguruan.

4. Jumlah mahasiswa pada Fakultas Tarbiyah dan Keguruan cukup banyak. $^{10}$

Adapun kelemahan Fakultas Tarbiyah dan Keguruan yaitu;

1. Laboratorium yang kurang mencukupi.

2. Disiplin dosen yang kurang memuaskan

3. Masih banyak dosen mengunakan pola-pola lama dalam pembelajaran

4. Sistem penbagian proporsi pembimbingan dan pengujian kurang merata

5. Sistem pembagian tugas kurang kompetitif.

6. Kurangnnya pemberian keterampilan dan pengembangan diri pada Mahasiswa $^{11}$

\footnotetext{
${ }^{10}$ Rosmiaty Asiz, dosen Fakultas Tarbiyah dan Keguruan UIN Alauddin Makassar wawancara di Makassar pada tanggal 16 Agustus 2017.

${ }^{11}$ H. Andi Achru, dosen Fakultas Tarbiyah dan Keguruan UIN Alauddin Makassar wawancara di Makassar pada tanggal 16 Agustus 2017.
} 
Dari penjelasan di atas secara nalar sehat dapat direncanakan ialah mengunakan kesempatan sebaik-baiknya, mencoba mengantisipasi dan mengulangi ancaman, mengunakan kekuatan sebagai modal dasar operasi dan memanfaatkannya semaksimal mungkin serta mengusahakan untuk mengurangi atau menghilannkan kelemahan yang masih ada.

Pengelolaan pendidikan pada Fakultas Tarbiyah dan Keguruan UIN Alauddin Makassar mengacu pada:

1. Efisiensi dan Efektivitas Kepemimpinan

Berdasarkan peraturan yang berlaku dan menjadi pedoman utama pengelolaan program, Efisiensi dan efektifitas kepemimpinan di Fakultas Tarbiyah dan Keguruan UIN Alauddin Makassar selalu diupayakan, melalui kebijakan yang tepat, prosedur yang sederhana, pengambilan keputusan secara cepat dan benar. Di samping itu, selalu diadakan rapat terjadwal untuk membahas masalah-masalah tertentu yang urgen dan real, dengan mengedepankan kepentingan bersama dan kemaslahatan umum yang diambil berdasarkan azas musyawarah/demokratis, dan bukan otoriter.

Kepemimpinan dan pengelolaan lembaga Fakultas Tarbiyah dan Keguruan UIN Alauddin Makassar yang ada sekarang cukup memadai dilihat dari latar belakang pendidikan dan pengalamannya. Dalam menyebarluaskan kebijakan, unsur pimpinan berusaha menempuh sistem dan strategi tertentu antara lain: menyiapkan dan melaksanakan pengendalian administrasi dalam kegiatan organisasi agar terarah sesuai tujuan, menciptakan sistem administrasi yang terpadu dalam menjamin terciptanya pengambilan keputusan yang efektif dan efisien, serta menetapkan sistem administrasi sesuai dengan perkembangan agar dapat memberikan informasi secara cepat, tepat dan benar. ${ }^{12}$

2. Evaluasi Program Pembelajaran

Untuk mengetahui berjalan tidaknya program yang telah dicanangkan, Fakultas Tarbiyah dan Keguruan UIN Alauddin Makassar selalu melakukan Evaluasi secara terjadwal dan berkesinambungan. Evaluasi ini dimulai dari perencanaan program, pelaksanaan, pencapaian sasaran, dan faktor yang mempengaruhi program. Evaluasi ini dilakukan oleh dekan dan pembantu dekan Fakultas Tarbiyah UIN Alauddin Makassar, baik melalui rapat pimpinan, rapat koordinasi akademik, rapat

\footnotetext{
${ }^{12}$ H. Andi Achru, dosen Fakultas Tarbiyah dan Keguruan UIN Alauddin Makassar wawancara di Makassar pada tanggal 16 Agustus 2017.
} 
umum dengan semua civitas akademika, rapat kerja tahunan, dan pelacakan terhadap sasaran program.

Adapun pelacakan sasaran program, termasuk pelacakan lulusan Fakultas Tarbiyah UIN Alauddin Makassar dilakukan melalui pengamatan dan wawancara langsung, pertemuan rutin tahunan. Orientasi menggalang rasa persatuan dan menjamin komunikasi alumni dalam upaya menunjang pencapaian tujuan pendidikan di lingkungan Fakultas Tarbiyah dan Keguruan UIN Alauddin Makassar benar-benar menyadari bahwa lulusan dengan perannya merupakan salah satu potensi utama untuk terus berkembang di masyarakat. Melalui kerjasama dan hubungan yang dibina secara khusus dengan alumni, Fakultas Tarbiyah dan Keguruan UIN Alauddin Makassar akan mendapatkan masukan bagi peningkatan kualitas tri darma dan dukungan bagi pengembangan jumlah penerimaan Fakultas Tarbiyah dan Keguruan UIN Alauddin Makassar. ${ }^{13}$

Hasil dari pelacakan alumni tersebut telah dimanfaatkan oleh pimpinan universitas untuk peningkatan perbaikan program dan perencanaan program yang lebih baik di masa mendatang. Perbaikan program yang telah dilakukan adalah penyempurnaan kurikulum yang berbasis nilai, perbaikan sarana dan prasarana gedung dan ruang kuliah, perbaikan sarana perkuliahan, dan peningkatan pelayanan administratif yang kondusif, cepat, tepat dan ramah.

3. Perencanaan dan Pengembangan Program

Berpijak pada hasil evaluasi program, baik secara internal maupun eksternal, Fakultas Tarbiyah dan Keguruan UIN Alauddin Makassar melakukan perencanaan dan pengembangan program yang lebih terarah, menyangkut proses implementasi tri darma. Dengan tetap mepertimbangkan keterbatasan sumber daya, baik biaya, waktu, maupun kendala-kendala lainnya, Fakultas Tarbiyah dan Keguruan UIN Alauddin Makassar melakukan perencanaan dan pengembangan program difokuskan pada visi, misi, tujuan, dan kebutuhan masyarakat pengguna.

Pendidikan Islam khususnya dalam pengembangan perguruan tinggi agama Islam pada mulanya didorong oleh beberapa tujuan, yaitu: pertama, untuk melaksanakan kajian dan pengembangan ilmu-ilmu agama Islam pada tingkat yang lebih tinggi secara lebih sistematis dan terarah, kedua, untuk melaksanakan pengembangan dan peningkatan dakwah Islam, dan ketiga, untuk melakukan reproduksi dan kaderisasi

\footnotetext{
${ }^{13}$ Syaharuddin Pembantu Dekan III pada Fakultas Tarbiyah dan Keguruan UIN Alauddin Makassar Wawancara di Makassar pada tanggal 4 September 2017.
} 
ulama dan fungsionaris keagamaan baik di kalangan birokrasi negara maupun sektor swasta, serta lembaga-lembaga sosial, dakwah, pendidikan, pada seluruh elemen bangsa dan tak terkecuali masyarakat kepulauan.

Sedangkan pengembangan program empat tahunan dilakukan melalui strategi konsolidasi dan peningkatan mutu. Konsolidasi, dapat juga diartikan sebagai stabilitas, dilakukan sebagai upaya untuk memantapkan persyaratan dan mengokohkan eksistensi Fakultas Tarbiyah dan Keguruan UIN Alauddin Makassar dan peningkatan mutu, dilakukan sebagai upaya untuk meningkatkan kualitas Fakultas Tarbiyah dan Keguruan UIN Alauddin Makassar sebagai institusi pendidikan yang mampu menjawab berbagai tantangan dan kebutuhan masyarakat atas ilmu pengetahuan dan teknologi, serta mampu bersaing (kompetitif) dalam menarik mahasiswa dan menghasilkan produk sarjana dan profesional unggulan dan memiliki kepedulian sosial. ${ }^{15}$

Dalam tiga tahun terakhir ini, prioritas perencanaan dan pengembangan fakultas tidak dilakukan penentuan prioritas pengembangan berdasarkan bidang (akademis dan administratif dengan berbagai komponennya), tetapi dilakukan berdasarkan tingkat prioritas atas tinjauan rencana/program/proyek. Tentunya dengan metode perencanaan startegi dan pengembangan strategi konsolidasi dan peningkatan mutu. Untuk mencapai sasaran ini dilakukan dengan melihat sistem pendidikan yang komperhensif dan integral dari masing-masing unsur komponen akademis dan administrasi, dengan meninjau keterkaitan antar masing-masing unsur. ${ }^{16}$

4. Kerjasama dan Kemitraan

Dengan berpedoman pada Keputusam Menteri Pendidikan Nasional No 223/U/1998 tentang Kerjasama Antar Perguruan Tinggi. Fakultas Tarbiyah UIN Alauddin Makassar memandang kerja sama dan kemitraan sebagai strategi yang perlu dikembangkan untuk pembinaan dan pengembangan Fakultas Tarbiyah dan Keguruan UIN Alauddin

\footnotetext{
${ }^{14}$ Muhaimin, Rekontruksi Pendidikan Islam dari Paradigma Pengembangan Manajemen Kelembagaan, Kurikulum hingga strategi Pembelajaran (Cet. I; Jakarta: PT. Raja Grafindo Persada, 2099), h. 240.

${ }^{15}$ Moh. Ibnu Sulaiman Mantan PD.I Fakultas Tarbiyah dan Keguruan UIN Alauddin Makassar periode 2008-2011 Wawancara di Makassar pada tanggal 4 September 2011.

${ }^{16}$ Syaharuddin Pembantu Dekan III pada Fakultas Tarbiyah dan Keguruan UIN Alauddin Makassar Wawancara di Makassar pada tanggal 4 September 2017.
} 
Makassar. Program Studi telah meningkatkan kerja sama dan kemitraan dengan Perguruan Tinggi/lembaga lain, baik instansi pemerintah maupun swasta. Kerja sama yang telah dilakukan adalah dalam implementasi tridarma. Dalam pendidikan dan pengajaran, kerjasama dilakukan dengan Pesantren Madani Pao-Pao, MTsN Model, MAN Model, MAN 1, SMP Muhammadiyah Makasasar tentang praktek keguruan, dengan Kemenag RI tentang peningkatan mutu tenaga pendidik dan kependidikan, dengan MTs,SMP,MA,SMU,SMK di lingkungan Fakultas Tarbiyah UIN Alauddin Makassar tentang pelatihan aplikasi mengajar atau Pendidikan dan Latihan Pendidikan Guru (PLPG). ${ }^{17}$

Kerja sama dan kemitraan tersebut, baik kuantitas maupun kualitasnya, masih terus ditingkatkan hingga sekarang, dengan lembaga yang telah bekerja sama maupun lembaga lainnya.

5. Dampak hasil evaluasi Program terhadap pengalaman dan Mutu Pembelajaran Mahasiswa

Hasil evaluasi program tersebut, baik secara internal maupun eksternal, terutama aspek kelemahan (weakness) berkaitan belum optimalnya implementasi program dijadikan tolak ukur oleh Fakultas Tarbiyah dan Keguruan UIN Alauddin Makassar untuk peningkatan mutu pembelajaran yang berbasis transformatif kepada mahasiswa, sehingga mengalami peningkatan dari tahun ke tahun. Hal ini dapat dibuktikan antara lain dengan adanya peningkatan intensitas dan metode pembelajaran yang berbasis transformatif, sarana dan prasarana pembelajaran, dan mutu lulusan.

Studi tentang pendidikan tinggi Islam di Indonesia, dapat dikategorikan dalam empat aliran model berpikir. Pertama, mereka yang terjebak dalam paradigma ilmu-ilmu sekuler. Kedua, mereka yang terjebak dalam model paradigma berpikir ulama-ulama fiqh masa klasik. Ketiga, mereka yang mencoba mengawinkan antara model berpikir sekuler dengan model berpikir ulama klasik. Keempat mereka yang mencoba keluar dari ketiga jenis model paradigma itu dan mencoba membangun paradigma baru yang disebut dengan paradigma Islam transformatif. ${ }^{18}$

\footnotetext{
${ }^{17}$ Syaharuddin Pembantu Dekan III pada Fakultas Tarbiyah dan Keguruan UIN Alauddin Makassar Wawancara di Makassar pada tanggal 4 September 2017.

${ }^{18}$ Ian G.Barbaur, Isues In Science and Religion (Cet. I; New York: Harper \& Row, 1997), h. 177.
} 
Sementara itu, Kuntowijoyo menawarkan paradigma Islam sebagai model kerangka berpikir yang mencerminkan Islam sebagai identitas. Dengan latar sebagai seorang sejarawan dan budayawan, ia mencoba memahami Islam dari perspektif itu dan mencoba menawarkan model memahami Alquran dari ketiga konsep tersebut. Menurutnya gerakan Islamisasi ilmu yang dilancarkan oleh beberapa tokoh seperti al-Faruqi, Sardar, Muzaffar dan para pendukung lainya. Baginya langka awal yang mendesak dilakukan oleh umat Islam dan lembaga Pendidikan Islam pada khususnya dalam rangka pembentukan identitas Islam secara menyeluruh adalah memahami Alquran dengan kerangka ilmu, terutama dalam hal ini adalah ilmu-ilmu sosial dan humanis. ${ }^{19}$

Mengembangkan pendidikan tinggi Islam di Indonesia tidak akan pernah lepas dari setumpuk persoalan dilematis yang selama ini masih dan sedang mengungkumnya, baik masalah kebijakan, pengelolaan, penyelenggara pendidikan, kurikulum, dan lain sebagainya. ${ }^{20}$ Kondisi pendidikan saat ini tentu tidak bisa lepas dari era sebelumnya, yakni pengelolaan pendidikan di era orde baru yang sentralistik. Untuk merumuskan orientasi pendidikan masa depan dalam era desentralistik atau otonomisasi saat ini perlu belajar dari praktik sentralisasi pendidikan yang dijalankan pada masa orde baru tersebut. Hal ini dimaksudkan, supaya perubahan tidak hanya bersifat labelitas belaka, namun secara nyata. Sebab dengan refleksi tersebut sehingga tidak terjebak pada lubang yang sama, khusunya terhadap kebijakan penguasa yang hegemonik.

\section{Usaha yang Ditempuh dalam Pengembangan Pendidikan Islam Pada Fakultas Tarbiyah dan Keguruan UIN Alauddin Makassar}

Seringkali ada perasaan takut dan khawatir ketika sebuah pemikiran alternatif dimunculkan. Pemikiran alternatif yang muncul ke permukaan sering diikuti perasaan takut, terlebih jika ia bersinggungan atau bahkan berhadapan dengan penyelenggara pendidikan. Sebahagian dosen khususnya di lingkungan Fakultas Tarbiyah dan Keguruan UIN

\footnotetext{
${ }^{19}$ Lihat Kuntowijoyo, Paradigma Islam: Interpretasi untuk Aksi (Cet. II; Bandung: Mizan, 2007), h. 329.

${ }^{20}$ Mastuhu, Pendidikan Nasional Visioner (Cet. I; Jakarta: Lentera Hati, 2007), h. 38.

Bandingkan Lihat Mastuhu, Menata Ulang Sistem pendidikan Nasional dalam Abad 21 (Cet. II; Yogyakarta: Safiriah Insani Press, 2006),h. 153.
} 
Alauddin Makassar belum bisa menerima sepenuhnya pemikiranpemikiran yang inovatif karena dianggap menentang yang sudah ada. Tugas transformasi ini memang berat ibaratnya sedang berenang melawan arus. Namun pemikiran alternatif ini akan menjadi kenyataan apabila dijadikan sebagai ideologi besar yang kemudian mampu ideologi dominan yang selama ini mendominasi dunia pendidikan di Fakultas Tarbiyah dan Keguruan UIN Alauddin Makassar.

Pendidikan Islam pada Fakultas Tarbiyah dan Keguruan UIN Alauddin Makassar merupakan suatu proses yang direncanakan untuk mewujudkan suasana pembelajaran aktif dan kreatif agar peserta didik dapat mengembangkan potensi dirinya untuk memiliki kepekaan sosial dan kekuatan spiritual keagamaan bahkan Muhamad Room mengemukakan bahwa upaya pendidikan di samping berusaha untuk mengembangkan potensi-potensi fitrah manusia, juga berusaha untuk menyelamatkan dan melindungi fitrah manusia, serta menyelaraskan langkah perjalanan flthrah yang diciptakan Allah swt pada manusia yang berupa naluri, potensi jismiyah, nafsiyah, aqliyah, dan qalbiyah. Dengan demikian, manusia dapat lestari hidup di atas jalur kehidupan yang benar, atau di atas jalur ash-shirath al-mustaq $\overline{\text { imm }}{ }^{21}$

Pendidikan Islam dan Transformasi sosial yang meniscayakan emansipasi tentu akan menggeser kekuatan ideologi pendidikan yang hanya sekedar pengalihan ilmu pengetahuan saja. Pendidikan transformatif pada Fakultas Tarbiyah dan Keguruan UIN Alauddin Makassar menjadi penting karena adanya tantangan yang kuat dalam era ini. Salah satunya adalah transformasi nilal besar-besaran yang menciptakan konsekwensi logis munculnya budaya-budaya baru dan etos kerja sumber daya manusia. Kalau pendidikan masih mengandalkan pada aspek kognitif semata maka alumni Fakultas Tarbiyah dan Keguruan UIN Alauddin Makassar tentu akan ketinggalan jauh dengan universitas lain. Secara makro, era global adalah untuk merebut kompetensi SDM antar bangsa. Kualitas bangsa dibangun dari kualitas individu yang memiliki tanggung jawab terhadap diri masyarakatnya serta menghayati jati diri bangsa. ${ }^{22}$

\footnotetext{
${ }^{21}$ Muhammad Room, Dosen Fakultas Dakwah dan Komunikasi UIN Alauddin Makassar, Wawancara di Makassar pada tanggal 21 September 2017.

${ }^{22}$ Subair Umam Alumni Fakultas Tarbiyah dan Keguruan UIN Alauddin Makassar, wawancara di Makassar pada tanggal 21 Agustus 2017.
} 
Pendidikan Islam pada Fakultas Tarbiyah dan Keguruan UIN Alauddin Makassar pada era global ini menurut peneliti memiliki karakteristik yaitu pertama mengunakan akal sebagai alat pencari kebenaran dan pengukur kebenaran (rasionalisme), pengunaan akal dalam Islam bukan saja dibolehkan tetapi diharuskan tetapi ada hal-hal dalam Islam tidak membutuhkan penalaran tetapi yang dibutuhkan adalah keyakinan, kedua, manusia semakin materialis. Bersamaan dengan meningkatnya laju pembangunan fisik, seseorang juga menghadapi dilema yang sulit diselesaikan.

Tugas utama bagi penyelenggara pendidikan di Fakultas Tarbiyah dan Keguruan UIN Alauddin Makassar adalah menyusun perencanaan pendidikan yang diatur dalam sistem perundang-undangan pendidikan sehingga penerapan dari sistem perundang-undangan itu dapat digunakan para pelaksana atau para pelaku pendidikan sehingga tujuan pendidikan dapat tercapai.

Fakultas Tarbiyah dan Keguruan UIN Alauddin Makassar senantiasa mengembangkan nilai-nilai pembelajaran yang berbasis transformasi sosial yaitu penggunaan IPTEK dan tidak mengabaikan nilai-nilai moralitas dan nilai-nilai kemasyarakatan hal ini sejalan dengan visinya yakni Fakultas Tarbiyah dan Keguruan UIN Alauddin Makassar membentuk tenaga pendidik yang menguasai ilmu pengetahuan agama Islam dan meningkatkan kualitas tenaga pendidik baik aqidah, akhlak, sikap ilmiah maupun nilai-nilai sosial kemasyarakatan. ${ }^{23}$

Salah satu misi sentral pendidikan Fakultas Tarbiyah dan Keguruan UIN Alauddin Makassar adalah peningkatan Sumber Daya Manusia (SDM), yang benar-benar utuh, tidak hanya secara jasmaniah, tetapi juga secara batiniah. Peningkatan kualitas Sumber Daya Manusia itu dilaksanakan dengan keselarasan dengan tujuan misi profetis yaitu pertama, meningkatkan kinerja prodi baik prestasi akademik maupun non akademik melalui inovasi dalam input dan proses pembelajaran, kedua, meningkatkan kompetensi dan sistem penghargaan dosen, ketiga, meningkatkan mutu proses pembelajaran, mengembangkan bahan ajar serta memberikan bimbingan secara efektif, sehingga mahasiswa dapat berkembang secara optimal sesuai dengan potensi yang dimiliki, keempat, menciptakan lingkungan pengajaran dan lingkungan belajar dengan menggunakan teknologi modern, kelima, menumbuhkan

\footnotetext{
${ }^{23}$ Ridwan Idris, Dosen Fakultas Tarbiyah dan Keguruan UIN Alauddin Makassar, wawancara di Makassar pada tanggal, 15 September 2017.
} 
penghayatan terhadap ajaran agama yang dianut dan juga budaya bangsa sehingga menjadi sumber kearifan dalam bertindak, keenam, mengembangkan standar pencapaian ketuntasan kompetensi, serta meningkatkan prestasi intra dan ekstra kurikuler, ketujuh, meningkatkan persamaan dalam bidang pendidikan, kedelapan, menerapkan mekanisme partisipasi, kesembilan, mengembangkan standar penilaian.

Untuk mewujudkan visi Fakultas Tarbiyah dan Keguruan UIN Alauddin Makassar maka semua dosen mempunyai perang penting dalam peningkatan sumber daya manusia, sesuai dengan cirinya sebagai pendidikan agama, secara ideal Fakultas Tarbiyah dan Keguruan berfungsi dalam penyiapan calon guru yang memiliki sumber daya manusia yang berkualitas tinggi serta memiliki kompetensi sosial, baik dalam penguasaan terhadap ilmu pengetahuan dan teknologi maupun dalam hal karakter, sikap moral, serta penghayatan dan pengamalan ajaran agama. ${ }^{24}$ Secara ideal menurut penulis selaku dosen Tarbiyah dan Keguruan UIN Alauddin Makassar pendidikan berfungsi membina dan menyiapkan calon pendidik yang berilmu, berteknologi, berketerampilan tinggi, beriman, beramal shaleh dan memiliki kepedulian sosial.

Dalam kerangka perwujudan fungsi ideal pendidikan untuk meningkatkan kualitas sumber daya manusia tersebut, sistem pendidikan Islam haruslah senantiasa mengorientasikan diri untuk menjawab kebutuhan dan tantangan yang muncul dalam masyarakat khususnya di lingkungan Fakultas Tarbiyah dan Keguruan UIN Alauddin Makassar sebagai konsekwensi logis dari perubahan. Meski Indonesia telah mencapai kemajuan seperti itu, pembangunan tentu saja belum berakhir, Bahkan sebaliknya, Fakultas Tarbiyah dan Keguruan UIN Alauddin Makassar harus semakin meningkatkan momentum pendidikan dan senantiasa memperketat seleksi penerimaan calon mahasiswa baru di Fakultas Tarbiyah dan Keguruan UIN Alauddin Makassar karena keluaran nantinya akan menjadi tenaga pendidik yang mencerahkan masyarakat baik pada aspek lahiriah maupun batinia. Untuk itu, tidak ada alternatif lain, kecuali penyiapan calon pendidik yang memiliki sumber daya yang berkualitas tinggi dan dibarengi dengan nilai-nilai moralitas, menguasai ilmu pengetahuan dan teknologi, serta keahlian dan keterampilan. Hanya dengan tersedianya sumber daya manusia yang

\footnotetext{
${ }^{24}$ Syaharuddin Pembantu Dekan III pada Fakultas Tarbiyah dan Keguruan UIN Alauddin Makassar Wawancara di Makassar pada tanggal 4 September 2017.
} 
berkualitas tinggi itu, Fakultas Tarbiyah dan Keguruan UIN Alauddin Makassar bisa survive di tengah pertarungan ekonomi politik internasional. $^{25}$

Menurut Basnang Said alumni Fakultas Tarbiyah dan Keguruan UIN Alauddin Makassar dalam rangka meningkatkan kualitas pendidikan di lingkungan Fakultas Tarbiyah dan Keguruan UIN Alauddin Makassar maka hal yang harus dilakukan yaitu:

Pertama, Kurikulum Pendidikan Islam pada Fakultas Tarbiyah dan Keguruan UIN Alauddin Makassar disesuaikan dengan kondisi modern sehingga peserta didik memiliki pengetahuan terhadap makna dari arti kurikulum dan pengajaran itu. Memburu standar pendidikan sebagai target berkompetisi dengan perguruan tinggi lain juga tidak masalah, tetapi harus sebuah kejujuran dalam menilai kualitas pendidikan.

Kedua, Kompetensi Afektif menjadi prioritas terhadap nilai dari pendidikan yang diajarkan yaitu nilai yang bersandar pada prilaku dan etika. Sebanyak apapun ilmu yang dikuasai, sejumlah rumus dan ayatayat yang bagaimana pun dikuasai tetapi pendidikan nilai etika yang kurang menjadi kuranglah arti pendidikan itu. Nilai, tidak saja dapat diperoleh di bangku kuliah, tetapi di sekitar masyarakat pun terdapat seperangkat nilai yang tidak pernah habis.

Ketiga, menata komponen pengajar yang berkompeten pada bidangnnya dan berwawasan multikultural sehingga Fakultas Tarbiyah dan Keguruan UIN Alauddin Makassar dapat merumuskan pendidikan yang dibutuhkan saat ini, bukan pendidikan yang mengajarkan seperangkat dogma yang seakan-akan menjadi sesuatu yang tak mungkin lagi berubah, tetapi pendidikan yang memberi petunjuk untuk kemaslahatan. Keempat, substansi pendidikan adalah substansi nilai, sehingga nilai yang diajarkan setiap agama tidak akan bertentangan dengan nilai-nilai universal yakni nilai kemanusiaan. Kelima, menerapkan pendekatan dan metodologi pembelajaran pada Fakultas Tarbiyah dan Keguruan UIN Alauddin Makassar dengan mengunakan teknologi modern. ${ }^{26}$

\footnotetext{
${ }^{25}$ Basnang Said Alumni Fakultas Tarbiyah dan Keguruan UIN Alauddin Makassar, Wawancara di Makassar pada tanggal 17 September 2017.

${ }^{26}$ Basnang Said Alumni Fakultas Tarbiyah dan Keguruan UIN Alauddin Makassar, Wawancara di Makassar pada tanggal 15 September 2011.
} 
Menurut penulis pendidikan Islam pada Fakultas Tarbiyah dan Keguruan dalam kerangka transformasi sosial akan lebih menarik dan bermakna bagi peserta didik jika melibatkan lingkungan sekitar dan dunia nyata sebagai laboratorium dan media penelitian untuk menginternalisasi nilai-nilai Islam dalam kehidupannya, yaitu keyakinan yang diwujudkan dalam tindakan atau prilaku (akhlak) peserta didik. Pembelajaran transformatif dapat mengantarkan peserta didik sampai pada tahapan afeksi, dan tahapan psikomotorik, yang dilakukan dengan cara mengangkat topik-topik, isu-isu, tema-tema, dan problema-problema sosial keagamaan dan sosial kemasyarakatan yang kongkrit dan relevan. Topik-topik tersebut kemudian didiskusikan dan diteliti oleh peserta didik.

Ada beberapa prinsip umum sebagai upaya reorientasi pemikiran pendidikan transformasi sosial dalam konteks kekinian, yaitu: (1) tumbuhnya kesadaran kritis peserta didik, (2) berwawasan futuristik (masa depan), (3) pentingnya skill/keterampilan, (4) orientasi pada nilainilai humanis, dan (5) Adanya jaminan kualitas.

\section{Kesimpulan}

Peranan Fakultas Tarbiyah dan Keguruan UIN Alauddin Makassar dalam mengembangkan pendidikan Islam yaitu melakukan orientasi lembaga dalam menyuburkan dan mengembangkan eksistensi peserta didik seoptimal mungkin yang dilaksanakan melalui proses pendidikan yang bermartabat, kreatif, inovatif, experimentative, menumbuhkan dan mengembangkan bakat, minat, dan kemampuan peserta didik. Peranan Fakultas Tarbiyah dan Keguruan UIN Alauddin Makassar dalam mengembangkan pendidikan Islam mengisyaratkan bahwa pendidikan harus berfungsi dan relevan dengan kebutuhan, baik kebutuhan individu, keluarga maupun kebutuhan masyarakat. Untuk Pengembangan pendidikan Islam maka Fakultas Tarbiyah dan Keguruan UIN Alauddin Makassar perlu melakukan pembelajaran berbasis kontekstual, melakukan pembelajaran berbasis riset, penataan kurikulum yang berorientasi pada peningkatan kompetensi (paedagogik, kepribadian, sosial, dan profesional), serta memberi kemampuan adaptasi terhadap ketidakpastian lapangan kerja.

Usaha yang ditempu dalam pengembangan pendidikan Islam pada Fakultas Tarbiyah dan Keguruan UIN Alauddin Makassar dalam Kerangka Transformasi Sosial yaitu peningkatan Sumber Daya Manusia (SDM), yang benar-benar utuh, tidak hanya secara jasmaniah tetapi juga 
secara batiniah. Peningkatan kualitas SDM itu dilaksanakan dengan keselarasan dengan tujuan misi profetis yaitu pertama, meningkatkan kinerja lembaga atau prodi baik prestasi akademik maupun non akademik melalui inovasi dalam input dan proses pembelajaran, kedua, meningkatkan kompetensi dan sistem penghargaan dosen, ketiga, meningkatkan mutu proses pembelajaran, mengembangkan bahan ajar serta memberikan bimbingan secara efektif, sehingga mahasiswa dapat berkembang secara optimal sesuai dengan potensi yang dimiliki, keempat, menciptakan lingkungan pengajaran dan lingkungan belajar dengan mengunakan teknologi modern, kelima, menumbuhkan penghayatan terhadap ajaran agama yang dianut dan juga budaya bangsa sehingga menjadi sumber kearifan dalam bertindak, keenam, mengembangkan standar pencapaian ketuntasan kompetensi, serta meningkatkan prestasi intra dan ekstra kurikuler, ketujuh, meningkatkan persamaan dalam bidang pendidikan, kedelapan, menerapkan mekanisme partisipasi, kesembilan, mengembang-kan standar penilaian.

\section{Daftar Pustaka}

Aden Wijdan SZ, Pendidikan Islam dalam Perdaban Industrial. Cet. I; Yogyakarta: Adiyatya Media, 2007.

Azra,Azyumardi Paradigma Baru Pendidikan Nasional: Rekonstruksi dan Demokrasi Cet. I; Jakarta: Penerbit Kompas, 2009.

Barbaur, Ian G. Isues In Science and Religion. Cet. I; New York: Harper \& Row, 1997

Dhakiri,Muh. Khanif Paulo Freire, Islam dan Pembebasan. Cet. IV; Jakarta: Pena, 2008

Everet Reimer, School Is Dead diterjemahkan oleh M. Soedomo, Dengan judul Matinya Sekolah. Cet. II: Yogyakarta: Hanindita Graha Widia, 2005.

Fakih, Mansour Gagasan-gagasan politik Gramsci. Cet II; Yogyakarta: Pustaka Pelajar, 2007

Freire, Paulo The Politic Of Education; Culture, Power, and Liberation. Diterjemahkan oleh Agung Prihantoro, dengan judul Politik 
Pendidikan; Kebudayaan, Kekuasaan dan Pembebasan. Cet. VI; Yogyakarta: Pustaka Pelajar, 2007

Freire,Paulo Menggugat Pendidikan; Fundamentalisme, konservatisme, liberalCet. IV; Yogyakarta: Pustaka Pelajar, 2014.

Khun, Thomas The Structure of Revolution of Science. New York: John Wiley, 1999.

Kuntowijoyo, Paradigma Islam: Interpretasi untuk Aksi. Cet. II; Bandung: Mizan, 2007

Mastuhu, Menata Ulang Sistem pendidikan Nasional dalam Abad 21. Cet. II; Yogyakarta: Safiriah Insani Press, 2006.

Mastuhu, Pendidikan Nasional Visioner. Cet. I; Jakarta: Lentera Hati, 2007

Mastuhu, Sistem Pendidikan Nasional Visioner. Cet. III;Jakarta: Lentera Hati, 2010

Muhaimin, Rekontruksi Pendidikan Islam dari Paradigma Pengembangan Manajemen Kelembagaan, Kurikulum hingga strategi Pembelajaran. Cet. I; Jakarta: PT. Raja Grafindo Persada, 2009

Postman, Neil The End Of Education Diterjemahkan oleh Ade Ma'ruf bersama Siti Farida, dengan judul Matinya Pendidikan. Cet. III; Yogyakarta : Jendela. 2009.

Rembangy, Musthofa Pendidikan Transformatif Pergulatan Kritis Merumuskan Pendidikan di Tengah Pusaran Arus Globalisasi. Cet. I; Yogyakarta: Teras, 2010.

Rusli Karim, Pendidikan Islam di Indonesia; Antara Cita dan Fakta. Cet.I; Yogyakarta; Tiara Wacana, 2011.

Suyanto, Refleksi dan Reformasi Pendidikan di Indonesia. Cet. I; Yogyakarta: Adicita Karya Nusa, 2009.

Tilaar, H.A.R. Pendidikan, Kebudayaan dan Masyarakat Madani Indonesia. Cet. III; Bandung: PT Remaja Rosdakarya, 2014 